Niepełnosprawność. Dyskursy pedagogiki specjalnej

\title{
Klimat społeczny Młodzieżowych Ośrodków Wychowawczych - diagnoza i perspektywy rozwoju
}

Artykuł zawiera prezentację wyników badań empirycznych, których celem było zdiagnozowanie klimatu społecznego instytucji resocjalizacyjnych dla nieletnich. Grupę badawczą (badaną za pomocą Skali Klimatu Społecznego autorstwa R.H. Moosa, w polskiej adaptacji L. Pytki) stanowiło 412 wychowanków oraz 153 wychowawców z trzynastu młodzieżowych ośrodków wychowawczych. Przeprowadzona analiza wykazała, że klimat społeczny MOW jest najbardziej zbliżony do pozytywnie ocenianego modelu "opiekuńczo-wychowawczego". Uzyskane wyniki pozwoliły na sformułowanie praktycznych wskazówek i propozycji działań mających na celu kreowanie jeszcze bardziej konstruktywnego klimatu społecznego oraz wzmacnianie potencjału wychowawczego placówek resocjalizacyjnych dla nieletnich.

Słowa kluczowe: klimat społeczny, młodzieżowe ośrodki wychowawcze, efektywność resocjalizacji

\section{Youth Correctional Centers' social climate - diagnosis and development perspective}

The article includes a presentation of the results of the empirical research, whose purpose was to diagnose the social climate of correctional institutions for juvenile. The research sample (testing by the Scale of the Social Climate by Moos) was a group of 412 students and 153 teachers from thirteen Youth Correctional (Educational) Facilities. A survey revealed that the social climate of Youth Educational Centers is most similar to the type "caring-tutorial", which is rather positive. The results allowed to formulate the directions for the process of creating more constructive social climate of correctional institutions.

Keywords: the social climate, Youth Correctional (Educational) Facilities, the effectiveness of rehabilitation

\section{Wprowadzenie}

W literaturze z obszaru pedagogiki resocjalizacyjnej powszechny jest pogląd, że odpowiedni, korzystny klimat społeczny panujący w instytucji resocjalizacyjnej, 
nie tylko stanowi istotny wyznacznik jakości tej instytucji, ale również w znacznym stopniu determinuje postawy i zachowania osób uczestniczących w jej „życiu". Klimat społeczny najczęściej analizowany jest w kontekście innych, obiektywnych czynników warunkujących sukcesy i klęski pedagogiczne, stanowiąc niejako "soczewkę" skupiającą wpływy wszelkich czynników determinujących skuteczność realizacji, zakładanych przez aksjologię pedagogiczną, funkcji wychowawczych i resocjalizacyjnych [Pytka 2008, s. 165]. Z tego względu kształtowanie korzystnego klimatu społecznego powinno stać się podstawą, realizowanej $\mathrm{w}$ instytucjach resocjalizacyjnych, działalności organizacyjnej, socjotechnicznej oraz pedagogicznej.

\section{Podstawy teoretyczne analizowanego problemu}

\section{Definicja klimatu społecznego}

Instytucja resocjalizacyjna, traktowana jako środowisko wychowawcze, czyli swoiście powiązany układ warunków i cech, zróżnicowanych jakościowo i pełniących funkcję wychowawczo-resocjalizacyjną, wyznaczających przebieg i efekty procesu resocjalizacji, charakteryzowana jest $\mathrm{w}$ kategoriach: funkcji, ról społecznych, warunków, typu oddziaływań wychowawczych, ukierunkowania działań oraz warunków strukturalnych funkcjonowania instytucji. Zmienne te można sprowadzić do trzech wymiarów wyznaczających sposób działania instytucji ujmowanej jako środowisko wychowawcze: czynników materialno-ekonomicznych (podstawowe warunki działania), czynników kulturalnych (treści przekazu, wychowania i działań resocjalizacyjnych) oraz czynników psychospołecznych (mechanizmy wpływu wiążące się z relacjami interpersonalnymi), łącznie, choć z różną siłą, determinujących efektywność oddziaływań resocjalizacyjnych. Współcześnie przyjmuje się, że największe znaczenie wychowawczo-resocjalizacyjne mają tu czynniki społeczne, relacyjne, które wiążą się z mechanizmami przekazu (transmisji) elementów kulturowych, co koncepcyjnie można opisać w kategoriach klimatu społecznego instytucji [Wysocka 2008, s. 295].

We współczesnej pedagogice resocjalizacyjnej przyjmuje się, jako wiodące, teoretyczne ujęcie klimatu społecznego Rudolfa H. Moosa [1975], opisujące tę zmienną $\mathrm{w}$ terminach psychologicznych. Moos traktuje klimat społeczny jako swoistą osobowość instytucji (osobowość organizacyjna), której proces tworzenia się jest analogiczny do kształtowania się osobowości jednostki, czyli jest on efektem procesu rozwoju danej instytucji, w której wykształca się określony katalog zachowań jej członków, różnie charakteryzowanych, stanowiąc złożone i strukturalnie zróżnicowane zjawisko. Dla R.H. Moosa ów klimat to społeczna atmosfera 
środowiska edukacyjnego/wychowawczego, którego uczestnicy mają różne doświadczenia życiowe. W jego ramach Moos wyróżnia trzy obszary/wymiary:

1. "Relacje interpersonalne w obrębie instytucji” (Relationship Dimension) - wymiar ten pozwala ocenić zaangażowanie podopiecznych w wykonywanie codziennych zadań, ich ekspresję oraz udzielane wsparcie, np. zaangażowanie emocjonalne, spontaniczność, ekspresyjność, spójność grupy, podtrzymywanie emocjonalne, wsparcie okazywane podopiecznym przez kadrę itp.;

2. "Rozwój osobisty podopiecznych instytucji” (Personal Development Dimension) - wymiar ten pozwala na dokonanie oceny w zakresie nastawienia kadry na zaspokojenie potrzeb podopiecznych, zachęcania podopiecznych do „wglądu w siebie" oraz przygotowanie ich do opuszczenia instytucji, np. autonomia, orientacja na problemy praktyczne i osobiste, samodzielność, niezależność, orientacja na osiągnięcia, samopoznanie itp.;

3. "System organizacyjny instytucji” (System Maintenance and System Change Dimension) - wymiar ten pozwala na dokonanie oceny w zakresie systemu organizacyjnego danej instytucji, który może się przejawiać w strukturalnych i funkcjonalnych aspektach funkcjonowania instytucji - np. w jakim stopniu środowisko instytucji jest uporządkowane, jasne w swoich oczekiwaniach, utrzymuje kontrolę i reaguje na zmiany [Moos 1975, s. 19-25].

W oparciu o koncepcję Moosa, Lesław Pytka [2008, s. 164] zaproponował następującą, obejmującą całą złożoność omawianego zjawiska (jego istotę i funkcje), definicję klimatu społecznego instytucjonalnego środowiska wychowawczego: „zbiór subiektywnie postrzeganych przez wychowanków i wychowawców charakterystycznych cech, sytuacji i zdarzeń, będących względnie trwałymi skutkami funkcjonowania $\mathrm{w}$ ramach przyjętego systemu organizacyjnego i pedagogicznego, kształtujący motywacje i zachowania jednostek i grup społecznych tej instytucji". Istotę klimatu społecznego wyznacza więc subiektywność postrzegania określonych zjawisk występujących w instytucji [por. Bratnicki, Wyciślak 1980, s. 93; Adrjan 2008, s. 610] i trwałość pewnych jej elementów, funkcję zaś obrazują swoiste konsekwencje wynikające ze specyficznej atmosfery wychowawczej właściwej dla instytucji resocjalizacyjnej. Ujęcie to pozwala rozumieć klimat społeczny jako kategorię analizowaną zarówno z perspektywy jednostki funkcjonującej $w$ danym układzie instytucjonalnym (perspektywa subiektywna), jak i z perspektywy całego systemu, którego funkcją jest wpływanie na zachowania jednostki (perspektywa obiektywna) [Wysocka 2008, s. 297].

Zdaniem L. Pytki klimat społeczny instytucji resocjalizacyjnych warunkowany jest przez kilka grup czynników: pedagogiczną aksjologię, formalną strukturę placówki oraz metodykę oddziaływania wychowawczego, a bezpośrednio wpływa on na rozwój osobowy wychowanków, ich samowychowanie i samorealizację, a tym samym na efektywność procesu wychowawczego [Pytka 2008, s. 165-167]. 
Typy klimatu społecznego instytucji resocjalizacyjnych

Kluczową rolę, z punktu widzenia efektywności procesu resocjalizacji, odgrywa interpersonalny i emocjonalny aspekt klimatu społecznego.

W tym kontekście analizując społeczny klimat instytucji resocjalizacyjnej uwzględnia się: poczucie bezpieczeństwa, relacje między wychowankami, dbałość o integrację wewnątrz grup oraz relacje wychowawca-wychowanek, $w$ tym m.in.: podmiotowe, indywidualne traktowanie, sposób komunikacji, jakość wzajemnych kontaktów, ich budowanie i podtrzymywanie [Siemionow 2009, s. 95-96], czyli, innymi słowy - „sumujący się wobec zamierzeń i działań zbiór postaw osób z najbliższego kręgu społecznego" [Konopczyński 2006, s. 136]. Tak rozumiany klimat społeczny, nazywany przez Marka Konopczyńskiego również klimatem socjalizacyjnym, kształtuje więź emocjonalną warunkującą jakość życia społecznego w kontekście zaspakajania potrzeb, co z kolei w znacznej mierze kształtuje jakość stosunków interpersonalnych [Konopczyński 2009, s. 81].

Biorąc pod uwagę powyższe czynniki o charakterze relacyjnym, kształtujące specyficzny układ wymiarów/dymensji klimatu danej instytucji, można określić dominujący w niej klimat społeczny. Na podstawie dotychczasowych badań wyodrębniono cztery typy klimatu społecznego instytucji resocjalizacyjnych [Pytka 2008, s. 172-173]:

1. „Terapeutyczno-wychowawczy” - charakteryzuje się koncentracją na kształtowaniu poprawnych, przyjaznych, nasyconych pozytywnymi uczuciami stosunków interpersonalnych o wyraźnie terapeutycznym zabarwieniu, przy zredukowanych do minimum funkcjach kontrolno-represyjnych. Terapeutyczny potencjał tego klimatu wiąże się przede wszystkim z akceptującą, wspierająca, empatyczną i zaangażowaną postawą wychowawcy, otwartą, dwu- kierunkową i aktywną komunikacją oraz autentyczną i swobodną (aczkolwiek zgodną z panującymi regułami i zasadami kultury osobistej) ekspresją emocji uczestników interakcji wychowawczej.

2. "Opiekuńczo-wychowawczy" - nastawiony jest przede wszystkim na zaspokajanie potrzeb wychowanków i stymulowanie ich osobistego rozwoju poprzez zorientowanie wychowawców na pomoc w rozwiązywaniu problemów praktycznych i osobistych wychowanków. Proces ten przebiega w ogólnie pozytywnej atmosferze emocjonalnej (choć z reguły nie na tyle, aby umożliwić swobodną ekspresję emocji i w pełni otwartą komunikację) i raczej konstruktywnych - choć cechujących się umiarkowaną bliskością i otwartością - relacjach między wychowankami a wychowawcami. Dopiero na dalszym miejscu uwidaczniają się jako ważne parametry organizacyjne instytucji.

3. "Kontrolująco-opiekuńczy" - największy nacisk jest tu położony na kontrolę zachowania wychowanków i ład wewnątrzinstytucjonalny; mniejszy nieco - 
na przygotowanie praktyczne wychowanków do życia, a najmniejszy - na kształtowanie niekonfliktowych stosunków interpersonalnych. Taki obraz klimatu świadczy o niekorzystnych tendencjach $\mathrm{w}$ organizowaniu środowiska wychowawczego placówki.

4. "Kontrolująco-restrykcyjny” - największą wagę przywiązuje się w nim do przestrzegania zewnętrznej dyscypliny i do rygorów regulaminowych. W znacznie mniejszym stopniu zwraca się uwagę na kształtowanie poprawnych stosunków interpersonalnych. Natomiast zupełnie zaniedbuje się te elementy klimatu, które składają się na wytwarzanie terapeutycznego środowiska społeczności instytucjonalnej, tj. autonomię wychowanków i swobodę ekspresji. Klimat ten nie sprzyja nawiązywaniu i utrzymywaniu wartościowych więzi międzyludzkich opartych na wzajemnej przyjaźni, zaufaniu i cieple emocjonalnym. System społeczny placówki, w której dominuje ten typ klimatu jest nastawiony na konformizację wychowanków oraz niwelowanie różnic psychologicznych między nimi. $Z$ tego względu jest to typ klimatu społecznego najbardziej odbiegający od pożądanego modelu.

Przegląd wybranych badań na temat klimatu społecznego instytucji resocjalizacyjnych

Zdaniem Justyny Siemionow [2009, s. 95-96] wewnętrzny klimat instytucji może sprzyjać osiągnięciu określonych efektów podejmowanych działań resocjalizacyjnych lub też może być dla nich istotną barierą i przeszkodą. Wynika to z faktu, że niektóre środowiska społeczne, podobnie jak ludzie, są bardziej przyjazne i wspierające niż inne, zorientowane na zadania lub samokierujące. Różnią się także poziomem restrykcyjności i kontrolowania [Moos 1994/2003, s. 1]. Dla przykładu, analiza porównawcza wyników badań przeprowadzonych w latach 80. XX wieku w USA, Kanadzie, Jugosławii i Polsce, pozwoliła na ustalenie iż najkorzystniejszy - „terapeutyczno-wychowawczy” - klimat panował w placówkach resocjalizacyjnych w Kanadzie, instytucje jugosławiańskie charakteryzowały się klimatem „opiekuńczo-wychowawczym”, amerykańskie - „kontrolująco-opiekuńczym", zaś w polskich zakładach poprawczych, objętych w tamtych latach (1980) badaniami przez L. Pytkę, odnotowano, najbardziej odległy od pożądanego modelu, klimat "kontrolno-restrykcyjny" [Pytka 2008, s. 170-173]. Wyniki nowszych badań [Węgliński 2000; Sobczak 2007], pokazują, że na przestrzeni 20 lat burzliwych przemian ustrojowych, gospodarczych i kulturowych jakie dokonały się u schyłku XX wieku w Polsce, również w placówkach resocjalizacyjnych nastąpiła korzystna ewolucja. Najbardziej korzystne modyfikacje klimatu społecznego instytucji resocjalizacyjnych dla nieletnich w przestrzeni czasowej odnotował, na podstawie analizy porównawczej wyników badań z roku 1980 
i 2007, Sławomir Sobczak [2007]. Autor ten, badając wychowanków i kadrę pedagogiczną czterech placówek resocjalizacyjnych, ustalił, iż: „Obecny klimat społeczny instytucji resocjalizacyjnych koncentruje się na kształtowaniu poprawnych i przyjaznych relacji interpersonalnych, nasyconych pozytywnymi uczuciami, o wyraźnym terapeutycznym charakterze. Na drugim miejscu klasyfikuje się nastawienie na zaspokojenie potrzeb (...). Funkcje kontrolno-represyjne zostały zredukowane do minimum. W związku z tym, proces resocjalizacji w badanych placówkach odbywa się w klimacie terapeutyczno-opiekuńczym (...)" [Sobczak, 2007, s. 150]. Badania Andrzeja Węglińskiego, pokazują natomiast, że „klimat społeczny $\mathrm{w}$ internatowych grupach wychowawczych posiada cechy opiekuńczo-wychowawcze" [Węgliński 2000, s. 219]. Choć w porównaniu z jeszcze korzystniejszym klimatem panującym $\mathrm{w}$ placówkach rewalidacyjnych, w zakładach poprawczych "pojawiają się istotne utrudnienia w zakresie nawiązywania i utrzymywania, wśród nieletnich i ich wychowawców, szczególnie wartościowych więzi międzyludzkich opartych na przyjaźni, zaufaniu i cieple emocjonalnym" [Węgliński 2000, s. 221]. Również badania Grzegorza Zalewskiego [2004] ujawniły istotne różnice $\mathrm{w}$ zakresie klimatu społecznego w zależności od typu placówki resocjalizacyjnej dla nieletnich. Badania te dowiodły bowiem, że w percepcji wychowanków klimat społeczny Młodzieżowych Ośrodków Adaptacji Społecznej, Zakładów Poprawczych typu otwartego oraz Zakładów Poprawczych dla dziewcząt jest istotnie korzystniejszy niż klimat w bardziej restrykcyjnych placówkach (Zakładach Poprawczych typu zamkniętego i o wzmożonym nadzorze) [Zalewski 2004, s. 78-115]. Z kolei badania Anety Skuzy z 2009 roku ujawniły, że dominującym klimatem społecznym $\mathrm{w}$ polskim zakładzie poprawczym jest klimat "kontrolująco-restrykcyjny”, w którym pomimo widocznych prób kształtowania poprawnych, przyjaznych stosunków interpersonalnych, zbyt duży nacisk kładzie się na przestrzeganie zewnętrznej dyscypliny i rygorów regulaminowych oraz zupełnie zaniedbuje się te elementy klimatu, które składają się na wytwarzanie terapeutycznego środowiska społeczności instytucjonalnej (autonomię wychowanków oraz swobodę ekspresji) [Skuza 2012, s. 367]. Podobnie niekorzystny klimat występuje, zdaniem Magdaleny Staniaszek [2016], również w Młodzieżowych Ośrodkach Wychowawczych.

Jak widać, wyniki dotychczasowych badań dotyczących klimatu społecznego polskich placówek resocjalizacyjnych dla nieletnich są bardzo zróżnicowane i wewnętrznie sprzeczne, przez co nie pozwalają na jednoznaczne określenie klimatu społecznego panującego w tych instytucjach. Pojawiające się w literaturze przedmiotu zróżnicowanie ocen rodzaju klimatu społecznego ośrodków dla nieletnich może wynikać z faktu, iż każda badana placówka posiada swój niepowtarzalny klimat społeczno-wychowawczy, co w znacznej mierze utrudnia uśrednianie wyników i generalizowanie wniosków w odniesieniu do wszystkich placówek reso- 
cjalizacyjnych w kraju. Warto również uwzględnić fakt, iż narzędzie do badania klimatu społecznego - Skala Klimatu Społecznego Instytucji Korekcyjnej według Moosa [1975] w polskiej adaptacji L. Pytki [por. Pytka 2008, s. 409-412] - daje dużą swobodę interpretowania uzyskanych wyników i określania na ich podstawie rodzaju klimatu społecznego, co może niekiedy zniekształcać i zaciemniać obraz diagnostyczny badanego zjawiska.

Jakkolwiek niezależnie od pewnych trudności interpretacyjnych i metodologicznych wynikających z szerokiego zakresu i niejednoznaczności pojęcia klimatu społecznego, bez wątpienia - ze względów prakseologicznych - jest ono w resocjalizacji niezbędne i powinno być poddawane regularnej diagnozie.

\section{Podstawowe założenia metodologiczne przeprowadzonych badań}

\section{Uzasadnienie i cel podjętych badań}

Zainteresowanie podjętą problematyką wynika z faktu, iż badania klimatu placówek resocjalizacyjnych dla nieletnich nie przyniosły dotychczas jednoznacznej odpowiedzi na pytanie o jego typ i jakość. Właściwa diagnoza klimatu społecznego polskich instytucji resocjalizacyjnych dla nieletnich jest niezmiernie istotna zarówno z praktycznego (diagnostycznego i metodycznego) punktu widzenia, jak też z punktu widzenia efektywności oddziaływań resocjalizacyjnych wobec nieletnich [Moos 1994/2003; Konopczyński 2006, 2009; Pytka 2008; Wysocka 2008]. Dodatkowo, problem ten nabiera szczególnego znaczenia w kontekście trwającej aktualnie debaty nad kształtem całego systemu resocjalizacji nieletnich w naszym kraju.

W związku z powyższym, celem podjętych badań było dokonanie diagnozy klimatu społecznego Młodzieżowych Ośrodków Wychowawczych na terenie Południowo-Zachodniej Polski.

\section{Problemy i hipotezy badawcze}

W ramach przyjętego diagnostyczno-opisującego modelu badań sformułowano następujące problemy badawcze:

1. Jak oceniają klimat społeczny Młodzieżowych Ośrodków Wychowawczych ich podopieczni i wychowawcy?

2. Czy istnieją istotne statystycznie różnice w ocenie klimatu społecznego (jego poszczególnych wymiarów) między wychowankami a wychowawcami MOW?

Z uwagi na swój opisowy charakter pierwszy problem badawczy nie wymaga formułowania hipotezy. Do drugiego problemu badawczego postawiono natomiast 
hipotezę, zgodnie z którą oceny klimatu społecznego formułowane przez wychowawców są korzystniejsze niż oceny wychowanków.

Podstawę sformułowania powyższego założenia stanowił fakt, iż w większości dotychczasowych badań klimatu społecznego placówek wychowawczych i resocjalizacyjnych, oceny wychowawców były dużo korzystniejsze niż oceny wychowanków [Pytka 1984, 2008; Zalewski 2004; Skuza 2012; Karłyk-Ćwik 2016].

\section{Grupa badawcza i teren badań}

Badaniami objęto grupę 412 wychowanków oraz 153 wychowawców i nauczycieli-wychowawców z trzynastu wybranych w sposób celowo-losowy Młodzieżowych Ośrodków Wychowawczych na terenie Dolnego Śląska i Opolszczyzny. W grupie wychowanków, dla których średnia wieku to 16 lat, znalazło się 134 dziewczęta i 278 chłopców, zaś w grupie wychowawców (średnia wieku - 40 lat) 89 kobiet i 64 mężczyzn.

Teren badań stanowiły Młodzieżowe Ośrodki Wychowawcze (dalej MOW) przeznaczone dla dzieci i młodzieży niedostosowanych społecznie w wieku od 13 do 18 lat, umieszczanych na mocy postanowień Sądów Rodzinnych, wymagających stosowania specjalnej organizacji nauki, metod pracy, wychowania i resocjalizacji. Diagnozę przeprowadzono w następujących Ośrodkach: MOW w Brzegu Dolnym, MOW w Iwinach, MOW w Mrowinach, MOW w Namysłowie, MOW w Nysie, MOW w Oławie, MOW w Sobótce, MOW w Stobrawie, MOW w Szklarskiej Porębie, MOW w Wałbrzychu, MOW we Wrocławiu, ul. Borowska, MOW we Wrocławiu, ul. Pl. Grunwaldzki, MOW w Zawiści.

\section{Metoda i narzędzie badawcze}

Narzędziem badawczym wykorzystanym $\mathrm{w}$ prezentowanych samoopisowych badaniach była Skala Klimatu Społecznego Instytucji Korekcyjnej wg R. Moosa [1975], w polskiej adaptacji L. Pytki [2008, s. 409-412]. Skala Klimatu Społecznego (SKS), składająca się z 90 pytań, zawiera 9 podskal tworzących 3 wymiary klimatu społecznego:

1. "Zaangażowanie" - stopień zaangażowania wychowawców i wychowanków w realizację ich codziennych zadań i obowiązków;

2. "Podtrzymywanie" - nasilenie i rodzaj zachęt stosowanych przez wychowawców oraz poziom „wsparcia emocjonalnego" wychowanków przez wychowawców;

3. „Ekspresja” - stopień swobody ekspresji, tj. zakresu swobody wychowanków w wyrażaniu uczuć, $\mathrm{w}$ tym także uczucia wrogości w stosunkach interpersonalnych; 
4. „Autonomia” - stopień samodzielności wychowanków w codziennym postępowaniu;

5. „Orientacja praktyczna” - poziom działalności instytucji w zakresie rozwiązywania problemów praktycznych wychowanków, takich jak nauka szkolna czy przygotowanie zawodowe i do samodzielnego życia w społeczeństwie;

6. "Orientacja na problemy osobiste" - poziom umiejętności wychowanków dokonywania "wglądu w siebie" i pokonywania wewnętrznych trudności motywacyjnych i emocjonalnych, a także pomoc ze strony kadry w tym zakresie;

7. „Porządek i organizacja” - skłonność wychowawców do przestrzegania zewnętrznych przejawów ładu i porządku oraz dyscypliny wewnątrzinstytucjonalnej;

8. "Jasność celów, zadań, regulaminów" - stopień znajomości i zrozumienia przez wychowanków i wychowawców formalnych wymagań stawianych przez instytucję;

9. "Kontrola wychowawcza” - poziom skłonności wychowawców do spełniania funkcji kontrolnych w procesie wychowania [Pytka 2008, s. 168].

Trzy pierwsze podskale składają się na pierwszy wymiar klimatu społ., czyli "Relacje interpersonalne". Trzy kolejne podskale tworzą drugi wymiar klimatu, tj. „Rozwój osobisty podopiecznych”, zaś trzy ostatnie podskale, to wymiar trzeci - „System organizacyjny”. Zakłada się, że im wyższe są punktacje uzyskane w pierwszych sześciu podskalach (pierwsze dwa wymiary klimatu) oraz im niższe są one w trzech ostatnich (wymiar trzeci), tym bardziej sprzyjający jest klimat wychowawczy danej instytucji. Ponadto, im większe rozbieżności między oceną wychowawców i wychowanków, tym mniej korzystny jest klimat społeczny Placówki.

Uzyskane w badaniach parametry psychometryczne polskiej wersji SKS są zadowalające [Pytka 2008, s. 167-172; Zalewski 2004, s. 59-62].

\section{Organizacja i przebieg procesu badawczego}

Badania terenowe realizowano w okresie od października 2015 roku do czerwca 2016 roku. Zgromadzone dane poddano następnie analizie statystycznej: sprawdzono normalność rozkładu analizowanych zmiennych za pomocą testu Shapiro-Wilka, obliczono statystyki opisowe (średnie arytmetyczne (M), odchylenia standardowe (SD), medianę (Me), wariancję(W)), przeprowadzono test zgodności Chi-kwadrat dla określenia równoliczności porównywanych grup, a następnie zastosowano Test U Manna-Whitneya w celu porównania wyników uzyskanych przez dwie badane - statystycznie nierównoliczne - grupy. Obliczenia statystyczne wykonano przy użyciu programu komputerowego PQStat (v.1.6.2. 64-bit). 


\section{Prezentacja i dyskusja wyników przeprowadzonej diagnozy}

\section{Ocena klimatu społecznego Młodzieżowych Ośrodków Wychowawczych}

Poniżej zaprezentowano zestawienie średnich arytmetycznych ocen klimatu społecznego uzyskanych od wychowanków i wychowawców MOW (tab. 1).

Tabela 1. Ocena klimatu społecznego MOW z perspektywy wychowanków i wychowawców (zestawienie średnich arytmetycznych (M))

\begin{tabular}{|c|c|c|c|c|c|c|c|}
\hline \multicolumn{4}{|c|}{ Wychowankowie $\left(\mathrm{N}_{1}=412\right)$} & \multicolumn{4}{|c|}{ Wychowawcy $\left(\mathrm{N}_{2}=153\right)$} \\
\hline Podskala & $\mathrm{M}_{1}$ & Wymiar & $\mathrm{M}_{1}$ & Podskala & $\mathrm{M}_{2}$ & Wymiar & $\mathrm{M}_{2}$ \\
\hline Zaangażowanie & 6,985 & \multirow{3}{*}{$\begin{array}{l}\text { Relacje } \\
\text { inter- } \\
\text { personalne }\end{array}$} & \multirow{3}{*}{6,495} & Zaangażowanie & 7,993 & \multirow{3}{*}{$\begin{array}{l}\text { Relacje } \\
\text { inter- } \\
\text { personalne }\end{array}$} & \multirow{3}{*}{7,976} \\
\hline $\begin{array}{l}\text { Podtrzymywa- } \\
\text { nie emocjonalne }\end{array}$ & 7,170 & & & $\begin{array}{l}\text { Podtrzymywa- } \\
\text { nie emocjonalne }\end{array}$ & 8,765 & & \\
\hline Ekspresja & 5,311 & & & Ekspresja & 7,170 & & \\
\hline Autonomia & 6,376 & \multirow{3}{*}{$\begin{array}{l}\text { Rozwój } \\
\text { osobisty }\end{array}$} & \multirow{3}{*}{6,468} & Autonomia & 7,209 & \multirow{3}{*}{$\begin{array}{l}\text { Rozwój } \\
\text { osobisty }\end{array}$} & \multirow{3}{*}{8,085} \\
\hline $\begin{array}{l}\text { Orientacja } \\
\text { praktyczna }\end{array}$ & 6,461 & & & $\begin{array}{l}\text { Orientacja } \\
\text { praktyczna }\end{array}$ & 8,484 & & \\
\hline $\begin{array}{l}\text { Orientacja na } \\
\text { problemy osob. }\end{array}$ & 6,568 & & & $\begin{array}{l}\text { Orientacja na } \\
\text { problemy osob. }\end{array}$ & 8,562 & & \\
\hline $\begin{array}{l}\text { Porządek } \\
\text { organizacyjny }\end{array}$ & 6,879 & \multirow{3}{*}{$\begin{array}{l}\text { System } \\
\text { organiza- } \\
\text { cyjny }\end{array}$} & \multirow{3}{*}{6,468} & $\begin{array}{l}\text { Porządek } \\
\text { organizacyjny }\end{array}$ & 7,882 & \multirow{3}{*}{$\begin{array}{l}\text { System } \\
\text { organiza- } \\
\text { cyjny }\end{array}$} & \multirow{3}{*}{6,885} \\
\hline Jasność celów & 6,269 & & & Jasność celów & 7,261 & & \\
\hline Kontrola & 6,260 & & & Kontrola & 5,510 & & \\
\hline
\end{tabular}

Źródło: Opracowanie własne.

Z powyższego zestawienia wynika, że wychowankowie najwyżej oceniają podskale „Podtrzymywanie emocjonalne" $\left(\mathrm{M}_{1}=7,170\right)$, „Zaangażowanie” $\left(\mathrm{M}_{1}=6,985\right)$ oraz „Porządek organizacyjny” $\left(\mathrm{M}_{1}=6,879\right)$, najniżej zaś podskale: „Ekspresja” $\left(\mathrm{M}_{1}=5,311\right)$, „Kontrola” $\left(\mathrm{M}_{1}=6,260\right)$ oraz "Jasność celów” $\left(\mathrm{M}_{1}=6,269\right)$. Nieco inaczej sytuacja wygląda z perspektywy wychowawców, którzy najwyżej oceniają następujące podskale: „Podtrzymywanie emocjonalne" $\left(\mathrm{M}_{2}=8,765\right)$, „Orientacja na problemy osobiste" $\left(\mathrm{M}_{2}=8,562\right)$, "Orientacja praktyczna" $\left(\mathrm{M}_{2}=8,484\right)$ oraz "Porządek organizacyjny” $\left(\mathrm{M}_{2}=7,882\right)$, najniżej natomiast podskale: „Kontrola” $\left(\mathrm{M}_{2}=5,510\right)$, „Ekspresja" $\left(\mathrm{M}_{2}=7,170\right)$, „Autonomia” $\left(\mathrm{M}_{2}=7,209\right)$ i "Jasność celów" $\left(\mathrm{M}_{2}=7,261\right)$. Najwięcej rozbieżności dotyczy więc oceny podskal w obrębie dwóch pierwszych wymiarów klimatu społecznego: wychowankowie wyżej cenią zaangażowanie i skłonność do podtrzymywania emocjonalnego ujawniane przez wychowawców, zaś sami pedagodzy, oprócz podtrzymywania emocjonalnego, 
chętnie podkreślają swoją rolę we wspieraniu rozwoju osobistego wychowanków poprzez zorientowanie na rozwiązywanie ich problemów osobistych i praktycznych. Zaobserwowane różnice $w$ ocenach poszczególnych podskal przekładają się na różnicę w ocenie wymiarów klimatu społecznego. Otóż wychowawcy najwyżej oceniają wymiar „Rozwój osobisty” $\left(\mathrm{M}_{2}=8,085\right)$, zaś podopieczni - „Relacje interpersonalne" $\left(\mathrm{M}_{1}=6,495\right)$. Przy czym, zaznaczyć należy, że - wpisany w pierwszy wymiar klimatu społecznego („Relacje interpersonalne”) - „terapeutyczny potencjał" stosunków interpersonalnych na linii wychowawca-wychowanek wydaje się być mocno ograniczony przez nisko oceniany w obu grupach poziom ekspresji emocjonalnej wychowanków. Najniższe oceny obie grupy respondentów przypisały wymiarowi trzeciemu, jakim jest "System organizacyjny".

Dokonując oceny klimatu społecznego należy również uwzględnić fakt, iż oceny wychowanków są zbliżone do siebie we wszystkich wymiarach, co utrudnia jednoznaczną diagnozę typu klimatu panującego w badanych MOW.

Niemniej jednak, układ czynników/wymiarów ujawniony na podstawie diagnozy wychowawców i podopiecznych sugeruje, że klimat społeczny badanych Placówek ma charakter zbliżony do "opiekuńczo-wychowawczego" - zorientowanego przede wszystkim na zaspokajanie potrzeb oraz stymulowanie rozwoju wychowanków odbywające się w raczej poprawnie kształtowanych relacjach interpersonalnych opartych na zaangażowaniu i wspieraniu emocjonalnym, choć cechujących się umiarkowaną bliskością i otwartością. Jednak ten pozytywny obraz klimatu społecznego zakłóca fakt, iż obie badane grupy podkreślają skłonność wychowawców do wywierania dużego nacisku na przestrzeganie zewnętrznych przejawów ładu i porządku oraz dyscypliny wewnątrzinstytucjonalnej, przy jednoczesnym niskim stopniu znajomości i zrozumienia przez pracowników i podopiecznych formalnych wymagań stawianych im przez instytucję. Doświadczane przez obie badane grupy: formalizm, zewnętrzna dyscyplina, nacisk na przestrzeganie narzuconych, niejasnych reguł i wymuszanie konformizmu wobec nich stanowiące atrybuty instytucji o charakterze totalnym [Goffman 2006] - mogą znacząco obniżać jakość klimatu społecznego, zwłaszcza w jego interpersonalnym wymiarze. Wyrazem owej, nieco obniżonej jakości klimatu społecznego są niezbyt wysokie (średnio 6,5 pkt. na 10) - mieszczące się w granicach wyników przeciętnych - oceny poszczególnych podskal i wymiarów sformułowane przez wychowanków. Z tego względu zaleca się ostrożność w formułowaniu oceny typu i jakości klimatu MOW. 


\section{Różnice w ocenie klimatu społecznego wychowanków i wychowawców MOW}

Próbując określić jakość klimatu społecznego placówki, zakłada się, że im wyższe są punktacje uzyskane w pierwszych sześciu podskalach (pierwsze dwa wymiary klimatu) oraz im niższe są one $\mathrm{w}$ trzech ostatnich (wymiar trzeci), tym bardziej sprzyjający jest klimat wychowawczy danej instytucji. Ponadto, im większe rozbieżności między oceną wychowawców i wychowanków, tym mniej korzystny jest klimat społeczny Placówki.

O ile spełnienie pierwszego kryterium korzystnego klimatu społecznego badanych MOW zostało (choć nie bez zastrzeżeń) potwierdzone powyższymi wynikami, o tyle drugie kryterium - istnienie ewentualnych rozbieżności w ocenach wychowanków i personelu - może komplikować jednoznaczną ocenę jakości klimatu w badanych Placówkach (Tabela 2).

Tabela 2. Porównanie oceny klimatu społecznego wychowanków i wychowawców (Test U Manna-Whitneya)

\begin{tabular}{|l|c|c|c|c|c|c|c|c|}
\hline & \multicolumn{2}{|c|}{$\begin{array}{c}\text { Podopieczni } \\
\left(\mathrm{N}_{1}=412\right)\end{array}$} & \multicolumn{2}{|c|}{$\begin{array}{c}\text { Wychowawcy } \\
\left(\mathrm{N}_{2}=153\right)\end{array}$} & \multicolumn{4}{|c|}{ Test U Manna-Whitneya } \\
\hline $\begin{array}{l}\text { Wymiar Klima- } \\
\text { tu Społecznego }\end{array}$ & $\mathrm{Me} 1$ & $\begin{array}{c}\text { średnia } \\
\text { rang }\end{array}$ & $\mathrm{Me} 2$ & $\begin{array}{c}\text { średnia } \\
\text { rang }\end{array}$ & $\mathrm{U}$ & $\begin{array}{c}\mathrm{p} \\
(\mathrm{do}- \\
\text { kładne })\end{array}$ & $\mathrm{Z}$ & $\begin{array}{c}\mathrm{p} \\
\text { (asymp- } \\
\text { totyczne })\end{array}$ \\
\hline $\begin{array}{l}\text { Relacje } \\
\text { interpersonalne }\end{array}$ & 20 & 244,152 & 24 & 387,611 & $15512,5^{* *}$ & 0,0001 & $9,302^{* *}$ &, 000001 \\
\hline $\begin{array}{l}\text { Rozwój } \\
\text { osobisty }\end{array}$ & 20 & 237,541 & 25 & 405,412 & $12789^{* *}$ & 0,0001 & $10,885^{* *}$ &, 000001 \\
\hline $\begin{array}{l}\text { System } \\
\text { organizacyjny }\end{array}$ & 20 & 266,746 & 21 & 326,768 & $24821,5^{* *}$ & 0,0001 & $3,904^{* *}$ & 0,000095 \\
\hline
\end{tabular}

Uwaga: ** dla $\mathrm{p}=0,001$

Źródło: Opracowanie własne.

Ujawniono bowiem istnienie istotnych różnic statystycznych między ocenami klimatu społecznego dokonanymi przez wychowanków i wychowawców we wszystkich analizowanych wymiarach klimatu społecznego. Zgodnie z przyjętym założeniem (hipoteza nr 1) oraz wynikami dotychczasowych badań [Pytka 1984, 2008; Zalewski 2004; Skuza 2012; Karłyk-Ćwik 2016] oceny wychowawców są korzystniejsze niż oceny podopiecznych, co świadczy o różnym postrzeganiu rzeczywistości resocjalizacyjnej w zależności od pełnionej w niej roli społecznej.

Zdaniem Marka Kuleszy sposób percepcji rzeczywistości panującej w danej organizacji przez jednostki (bądź grupy jednostek) zdeterminowany jest konkret- 
nymi uwarunkowaniami osobowościowymi i sytuacyjnymi, a także osobistymi doświadczeniami, zainteresowaniami, wychowaniem i wzorcami kulturowymi, co $\mathrm{w}$ efekcie może prowadzić do powstawania różnic $\mathrm{w}$ ocenie panujących w instytucji realiów [Kulesza, 2011, s. 101-102]. Według S. Sobczaka [2007] różnice w ocenie podskal wchodzących w zakres wymiaru „Rozwój osobisty” wyjaśnić można odwołując się do Teorii Rozwoju Dojrzałości Interpersonalnej [Sullivan, Grant 1957; zob. też Pospiszyl, 1998, s. 163-175 ]. Zgodnie z przedstawioną w niej klasyfikacją osoby niedostosowane społecznie, znajdujące się na drugim, trzecim i czwartym poziomie rozwoju, cechują się dużym poziomem roszczeniowości oraz mało realistycznymi, często instrumentalnymi i niedojrzałymi oczekiwaniami w zakresie wsparcia i opieki. Zdaniem S. Sobczaka „Niedojrzałość budzi nieprawidłowe oczekiwania, którym kadra pedagogiczna prawdopodobnie nie jest $\mathrm{w}$ stanie w pełni zaradzić. $\mathrm{W}$ takim razie problem ten dotyczy niedojrzałości wychowanków, którzy nie są w stanie poradzić sobie z pokonywaniem trudności motywacyjnych i emocjonalnych" [Sobczak, 2007, s. 147]. Warto jednak mieć na uwadze, że źródło analizowanej rozbieżności w ocenie klimatu społecznego może również tkwić w samych wychowawcach. Badania Anny Karłyk-Ćwik [2009] ujawniły bowiem występowanie $w$ tej grupie zawodowej tendencji do (obronnego) zawyżania samooceny własnych działań zawodowych, obniżenie zdolności do krytycznej analizy i refleksji dotyczącej własnych działań podejmowanych w pracy z młodzieżą, a także skłonność do idealizacji oraz przeceniania swojej roli i aktywności w procesie resocjalizacji, ujawniającą się w bardzo częstym popełnianiu błędu „Eksponowania siebie" [Karłyk-Ćwik, 2009, s. 138-139, 238-245; Karłyk-Ćwik, 2012, s. 143-144].

Niezależnie od sposobu wyjaśniania, wysoki poziom rozbieżności w szacowaniu (ocenianiu) klimatu społecznego MOW przez wychowawców i podopiecznych sugeruje, że klimat ten jest mało korzystny i mało "efektywny” pod względem wychowawczym. Przyczyną (a także skutkiem na zasadzie sprzężenia zwrotnego) takiego stanu rzeczy jest poważne osłabienie procesów identyfikacji i przyswajania wzorów konstruktywnego zachowania się wychowanków, odbywających się na zasadzie wewnętrznej interioryzacji norm i wartości, których nosicielami są (powinni być) wychowawcy [Pytka, 2008, s. 173]. W tak niekorzystnych wychowawczo warunkach, pedagodzy stopniowo tracą zdolność skutecznego wywierania konstruktywnego wpływu wychowawczego na swoich podopiecznych [por. Gurycka 1997], co w znaczący sposób może obniżać efektywność procesu resocjalizacji. 


\section{Podsumowanie i wnioski}

Diagnoza klimatu społecznego Młodzieżowych Ośrodków Wychowawczych

Przeprowadzone badania diagnostyczne doprowadziły do ustalenia następujących faktów:

1. Wyłaniający się z badań obraz/układ wymiarów klimatu społecznego badanych placówek sugeruje, że ma on charakter zbliżony do „opiekuńczo-wychowawczego".

2. Pozytywna ocena klimatu społecznego instytucji resocjalizacyjnych dla nieletnich powinna być jednak formułowana ostrożnie z uwagi na to, iż:

a) oceny wychowanków są zbliżone do siebie we wszystkich wymiarach, co utrudnia jednoznaczną diagnozę typu klimatu panującego w badanych MOW;

b) oceny poszczególnych podskal i wymiarów sformułowane przez wychowanków są stosunkowo niskie, choć mieszczą się w granicach wyników przeciętnych;

c) choć wymiar "System organizacyjny" uplasował się w ocenie wszystkich badanych na ostatniej pozycji, to jednak - wyraźnie zaznaczone przez obie badane grupy - niekorzystne jego aspekty (m.in.: formalizm, zewnętrzna dyscyplina, nacisk na przestrzeganie narzuconych reguł przy braku ich rozumienia) mogą znacząco obniżać jakość klimatu społecznego, zwłaszcza $\mathrm{w}$ jego interpersonalnym wymiarze;

d) pomiędzy ocenami formułowanymi przez wychowanków i wychowawców istnieje duża (istotna statystycznie) rozbieżność (oceny wychowanków są mniej korzystne niż oceny wychowawców), co sugeruje, że klimat społeczny jest mało korzystny i mało „efektywny" pod względem wychowawczym.

Perspektywy rozwoju w zakresie kreowania konstruktywnego klimatu społecznego Młodzieżowych Ośrodków Wychowawczych

W procesie kreowania konstruktywnego klimatu społecznego i podnoszenia jego jakości pomocne mogą okazać się następujące działania:

1. Ograniczanie wpływu niekorzystnych aspektów systemu organizacyjnego instytucji resocjalizacyjnych na ich podopiecznych i pracowników, poprzez, m.in.: humanizowanie wzajemnych (zbyt formalnych) stosunków, utrzymywanie na optymalnym poziomie działań dyscyplinujących i nie nadużywanie rygoryzmu i środków kontroli, rozwijanie w wychowankach samodyscypliny 
i odpowiedzialności za siebie, wprowadzanie i konsekwentne przestrzeganie przejrzystych i zrozumiałych dla całej społeczności zakładowej reguł i zasad.

2. Stymulowanie rozwoju terapeutycznego charakteru klimatu społecznego $\mathrm{w}$ wymiarze relacji interpersonalnych, $\mathrm{m}$.in. poprzez zwiększenie przestrzeni dla swobodnej, aczkolwiek zgodnej z regułami panującymi w tego typu placówkach i zasadami kultury osobistej, ekspresji zwłaszcza trudnych emocji, np. złości, lęku, a także poprzez większą koncentrację kadry na problemach osobistych, potrzebach i emocjach wychowanków.

3. Udrażnianie swobodnej i otwartej, a jednocześnie bezpiecznej, komunikacji emocjonalnej, m.in. poprzez edukowanie wychowanków (w formie warsztatów psychoedukacyjnych oraz przez własny przykład wychowawców) w zakresie formułowania komunikatów typu "Ja" oraz informacji zwrotnych, a także poprzez wykorzystywanie i promowanie niekonwencjonalnych (symbolocznych) form bezpiecznej i bezkolizyjnej (niepowodującej konfliktów) ekspresji trudnych emocji, np. różnych form aktywności twórczej-arteterapii czy psychodramy [Konopczyński 2006, 2009] oraz aktywności humorystycznej [Karłyk-Ćwik 2015; Karłyk-Ćwik 2016a].

4. Zachęcanie do budowania autentycznych i silnych więzi emocjonalnych wychowawców z podopiecznymi, gdyż od stopnia bliskości, akceptacji, uczciwości i autentyczności tych relacji zależy $w$ dużej mierze poczucie bezpieczeństwa wychowanków (wyrażające się między innymi w autentycznej i otwartej ekspresji emocji), a co za tym idzie ich optymalny rozwój emocjonalny i społeczny.

5. Dostosowanie działań wychowawczych i terapeutycznych, podejmowanych przez personel w celu stymulowania rozwoju osobistego wychowanków, do indywidualnych i rzeczywistych potrzeb i problemów podopiecznych. W procesie tym warto opierać się na zindywidualizowanym, twórczym i pozytywnym (opartym na zasobach i wzmacnianiu pozytywnego potencjału) podejściu do wychowanków.

6. Podejmowanie różnorodnych działań ukierunkowanych na rozwijanie u podopiecznych umiejętności odpowiedzialnego podejmowania decyzji, motywowanie ich do rozwiązywania własnych problemów praktycznych oraz pokonywania trudności emocjonalnych, a także na przygotowanie wychowanków do samodzielnego funkcjonowania po opuszczeniu placówki, m.in. poprzez: stwarzanie wychowankom okazji do samodzielnego dokonywania wyborów i ponoszenia ich naturalnych konsekwencji, wspieranie prób samodzielnego rozwiązywania przez nieletnich ich życiowych problemów, włączanie wychowanków w procesy decyzyjne dotyczące ich codziennego funkcjonowania w placówce, a także zapewnienie podopiecznym jak najszerszego kontaktu ze środowiskiem otwartym w celu umożliwienia samodziel- 
nego załatwiania przez młodzież różnych codziennych spraw (sprawy urzędowe, szkolne, socjalno-bytowe).

7. Wzmacnianie rzeczywistego autorytetu wychowawców, a tym samym zwiększanie ich zdolności skutecznego wywierania konstruktywnego wpływu wychowawczego na podopiecznych, poprzez, m.in.: podnoszenie poziomu ich atrakcyjności społecznej i emocjonalnej (charyzmatyczna osobowość, poczucie humoru, zainteresowania i pasje dające zdolność aktywizowania innych oraz bycia dla nich wzorem i przykładem do naśladowania), rozwijanie umiejętności interpersonalnych (m.in.: otwartego i aktywnego komunikowania się, rozwiązywania konfliktów i redukowania napięć, rozpoznawania i empatycznego rozumienia emocji i potrzeb innych osób i własnych) oraz zdolności przywódczych (m.in.: kierowania grupą, uruchamiania synergii grupy, elastycznego dostosowywania stylu kierowania wychowawczego do typu sytuacji wychowawczej oraz potrzeb i poziomu dojrzałości podopiecznych, motywowania i aktywizowania wychowanków, radzenia sobie z presją i stresem).

Powyższe propozycje, choć nie wyczerpują dostępnego katalogu działań wzmacniających potencjał wychowawczy placówek resocjalizacyjnych, mogą jednak okazać się pomocne w procesie inicjowania i stopniowego wprowadzania pozytywnych zmian w organizacji i funkcjonowaniu Młodzieżowych Ośrodków Wychowawczych, zmierzających w kierunku budowania jeszcze bardziej korzystnego klimatu społecznego tych instytucji.

\section{Bibliografia}

Adrjan B. (2008), Klimat szkoty [w:] Encyklopedia pedagogiczna XXI wieku, t. 2, T. Pilch (red.), Wydawnictwo Akademickie "Żak", Warszawa.

Bratnicki M., Wyciślak M. (1980), Klimat organizacyjny: pojęcie, mierzenie, badania i diagnoza, „Prakseologia”, nr 4(76).

Goffman E. (2006), Charakterystyka instytucji totalnych [w:] Wspótczesne teorie socjologiczne, A. Jasińska-Kania, L.M. Nijakowski, J. Szacki, M. Ziółkowski (red.), Wydawnictwo Naukowe Scholar, Warszawa.

Gurycka A. (1997), O sztuce wychowania dla wychowawców i nauczycieli, CDN, Warszawa.

Karłyk-Ćwik A. (2009), Kompetencje zawodowe pedagogów w pracy z nieletnimi agresorami, Wydawnictwo Edukacyjne „Akapit”, Torun.

Karłyk-Ćwik A. (2012), Pedagog resocjalizacyjny - osobowe i profesjonalne aspekty roli w świadomości studentów resocjalizacji, „Niepełnosprawność. Półrocznik Naukowy”, nr 8.

Karłyk-Ćwik A. (2015), Humor w pracy pedagoga resocjalizacyjnego, „Niepełnosprawność. Dyskursy Pedagogiki Specjalnej", nr 18.

Karłyk-Ćwik A. (2016), Style humoru wychowanków i wychowawców a klimat społeczny placówek resocjalizacyjnych dla nieletnich, „Resocjalizacja Polska”, nr 12.

Karłyk-Ćwik A. (2016), Humor styles in socially maladjusted girls and boys: a resilience perspective, „CBU International Conference Proceedings", nr 4. 
Konopczyński M. (2006), Teoretyczne podstawy metodyki kulturotechnicznych oddziatywań resocjalizacyjnych wobec nieletnich. Zarys koncepcji twórczej resocjalizacji, PWN, Warszawa.

Konopczyński M. (2009), Metody twórczej resocjalizacji, PWN, Pedagogium, Warszawa.

Kulesza M. (2011), Klimat szkoty a zachowania agresywne i przemocowe uczniów, Wydawnictwo Uniwersytetu Łódzkiego, Łódź.

Moos R.H. (1974/1987), Correctional Institutions Environment Scale. Sampler Set. CA: Mind Garden Inc., Menlo Park.

Moos R.H. (1975), Evaluating Correctional and Community Settings, John Wiley\&Sons Inc., New York, London, Sydney, Toronto.

Moos R.H. (1994/2003), The Social Climate Scales: A User's Guide, CA: Mind Garden Inc., Menlo Park.

Pospiszyl K. (1998), Resocjalizacja. Teoretyczne podstawy oraz przykłady programów oddziaływań, Wydawnictwo Akademickie „Żak”, Warszawa.

Pytka L. (1984), Klimat społeczny instytucjonalnych środowisk wychowawczych, „Studia Pedagogiczne", t. XLVI.

Pytka L. (2008), Pedagogika resocjalizacyjna. Wybrane zagadnienia teoretyczne, diagnostyczne i metodyczne, Wydawnictwo APS, Warszawa.

Siemionow J. (2009), Efektywność oddziaływań instytucji resocjalizacyjnych a nowe trendy w resocjalizacji [w:] Wspótczesne kierunki zmian w teorii i praktyce resocjalizacyjnej, K. Konopczyński, W. Ambrozik (red.), Centrum Metodyczne Pomocy Psychologiczno-Pedagogicznej, Warszawa.

Skuza A. (2012), Klimat społeczny polskiego zakładu poprawczego (pedagogiczna analiza czynników kreujących), „Resocjalizacja Polska”, nr 3.

Sobczak S. (2007), Klimat społeczny instytucji resocjalizujacych. „Pedagogika Społeczna”, nr 3.

Staniaszek M. (2016), Postrzeganie młodzieżowych ośrodków wychowawczych przez ich wychowanków w kontekście klimatu społecznego [w:] Resocjalizacja - czarno na białym. Konteksty niedostosowania społecznego i ich praktyczne odniesienia, A. Karłyk-Ćwik, D. Rybczyńska-Abdel Kawy (red.), Wydawnictwo Akapit, Toruń.

Sullivan C.E., Grant M.Q. (1957), The Development of Interpersonal Maturity: Applications to Delinquency, „Psychiatry”, nr 20.

Węgliński A. (2000), Mikrosystemy wychowawcze w resocjalizacji nieletnich. Analiza pedagogiczna, UMCS, Lublin.

Wysocka E. (2008), Diagnoza w resocjalizacji, PWN, Warszawa.

Zalewski G. (2004), Klimat społeczny instytucji resocjalizacyjnych a poziom psychotyzmu u wychowanków, Wydawnictwo Leda, Białystok. 